\title{
STUART CLOTTING DEFECT. I. SEGREGATION OF AN HEREDITARY HEMORRHAGIC STATE FROM THE HETEROGENEOUS GROUP HERETOFORE CALLED "STABLE FACTOR" (SPCA, PROCONVERTIN, FACTOR VII) DEFICIENCY
}

\author{
BY CECIL HOUGIE,1 EMILY M. BARROW, AND JOHN B. GRAHAM
}

(From the Department of Pathology, University of North Carolina, Chapel Hill, N. C.)

(Submitted for publication August 24, 1956; accepted November 29, 1956)

In 1951, Alexander, Goldstein, Landwehr, and Cook (1) described a patient with a congenital hemorrhagic diathesis of an unusual type. There was a normal prothrombin concentration, but a prolonged prothrombin time which could be corrected by serum and serum fractions but not by $\mathrm{BaSO}_{4}$-adsorbed plasma or serum. The clotting factor deficient in the plasma of this patient differed, therefore, from prothrombin, Factor V, accelerator globulin (Ac-G), and antihemophilic factor (AHF). The normal analogue of the factor deficient in this patient was relatively heat stable, adsorbable by barium sulphate and diminished in dicoumarol plasma. The patient was believed to lack the precursor of SPCA (serum prothrombin conversion accelerator) a factor which had been studied previously (2).

Independently in 1951, Koller, Loeliger, and Duckert (3) and Owren (4) recognized the presence of clotting factors designated Factor VII and proconvertin, respectively. These two factors were believed to be identical with each other and with SPCA. Although the three terms have been used synonymously since that time, the literature shows no evidence that the identity has been rigorously established. Since the case of Alexander, Goldstein, Landwehr, and Cook (1), 29 other cases (Table I) of a congenital deficiency of these presumably identical factors have been described (5-24). Our present studies indicate that the patient of Crockett, Shotton, Craddock, and Leavell (25) also belongs in the same group. The thromboplastin generation test has been performed on 16 of the 31 patients. It has been normal in six, abnormal in nine, and questionable in one (see Table I). This suggests that the cases diagnosed as Factor VII deficiency, SPCA defi-

\footnotetext{
1 Present address: Department of Clinical Pathology, University of Virginia, Charlottesville, Virginia.
}

ciency and hypoproconvertinemia may be a heterogeneous group.

The following paper describes a follow-up study of one of the cases (R. S.) previously studied by Lewis, Fresh, and Ferguson (9). It will be shown that the factor deficient in this patient is similar to but not identical with the one lacking in the patient of Alexander (1), and is identical with the factor Crockett's patient lacks (25). These findings establish the heterogeneity of the group of patients listed in Table I. The factor our patient lacks will be referred to hereafter as the Stuart factor after the patient's surname. The present communication describes the properties of the Stuart factor and its role in blood coagulation. The mode of inheritance and certain other genetic considerations will be reported in a separate communication (26).

\section{MATERIALS}

Imidazole buffer, $\mathrm{pH} 7.3$, was prepared according to Mertz and Owen (27). Factor $V$ was prepared from plasma by the technique of Owren (28). Prothrombin was prepared from human plasma by the method of Biggs and Macfarlane (29). The Russell's viper venom ("Stypven") used in the experiments of Table III was the Burroughs Wellcome product in a $1: 10,000$ concentration, higher concentrations being inhibitory. In other experiments a 1:20,000 dilution was also used. Antihemophilic factor $(A H F)$ was a fraction of bovine plasma rich in AHF prepared by the method of Bidwell (30). It was used in a concentration of $100 \mathrm{mg}$. per $100 \mathrm{ml}$.

\section{METHODS}

Blood was collected, and plasma was prepared by methods previously described by Graham, McLendon, and Brinkhous (31). $A l(O H)_{3}$ adsorption was performed by the method of Biggs and Macfarlane (29). Serum factors adsorbed by this technique were eluted with a phosphate buffer at $\mathrm{pH} 8$. Clotting time was performed by the method of Lee and White (32). Pro- 
TABLE I

Summary of cases in literature

\begin{tabular}{|c|c|c|c|c|c|c|c|c|}
\hline \multirow[b]{2}{*}{ Case } & \multirow[b]{2}{*}{ Authors } & \multirow[b]{2}{*}{ Year } & \multirow[b]{2}{*}{ Sex } & \multirow{2}{*}{$\begin{array}{l}\text { Clinical } \\
\text { severity }\end{array}$} & \multicolumn{2}{|c|}{$\begin{array}{c}\text { Prothrombin time } \\
\text { (sec.) }\end{array}$} & \multirow{2}{*}{ 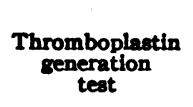 } & \multirow{2}{*}{$\begin{array}{l}\text { Effect of } \\
\text { "stypven" on } \\
\text { clotting time }\end{array}$} \\
\hline & & & & & Patient & Control & & \\
\hline \multirow{3}{*}{$\left.\begin{array}{l}1 \\
2 \\
3 \\
4 \\
5 \\
6\end{array}\right\}$} & $\begin{array}{l}\text { Crockett and associates (25) } \\
\text { Alexander and associates (1) } \\
\text { Beaumont and Bernard (5) }\end{array}$ & $\begin{array}{l}1949 \\
1951 \\
1953\end{array}$ & \multirow{2}{*}{$\begin{array}{l}\mathbf{F} \\
\mathbf{F} \\
\mathbf{M} \\
\mathbf{M} \\
\mathbf{F}\end{array}$} & \multirow{2}{*}{$\begin{array}{l}\text { Severe } \\
\text { Severe } \\
\text { Severe } \\
\text { Severe } \\
\text { Severe }\end{array}$} & \multirow{2}{*}{$\begin{array}{l}55 \\
72 \\
65 \\
55-60 \\
1-3 \% \mathrm{p}\end{array}$} & \multirow{2}{*}{$\begin{array}{l}14.2 \\
17 \\
13 \\
14 \\
\text { oconvertir }\end{array}$} & \multirow{2}{*}{$\begin{array}{l}\text { Abnormal* } \\
\text { Normal (43) } \\
\text { n }\end{array}$} & \multirow{2}{*}{$\begin{array}{l}\text { Not corrective } \\
\text { Corrective (39) }\end{array}$} \\
\hline & Owren (6) & 1953 & & & & & & \\
\hline & $\begin{array}{l}\text { Hagen and Watson (7) and } \\
\text { Frick and Hagen (8) }\end{array}$ & $\begin{array}{l}1948 \\
1953\end{array}$ & $\mathbf{F}$ & Severe & 52.5 & 12 & & \\
\hline \multirow{10}{*}{$\begin{array}{c}7 \\
8 \\
9 \\
10 \\
11 \\
12 \\
13 \\
14 \\
15 \\
16 \\
17 \\
18 \\
19 \\
20 \\
21 \\
22 \\
23 \\
24 \\
25 \\
26 \\
27 \\
28 \\
29 \\
30 \\
31\end{array}$} & Lewis and associates (9) & 1953 & \multirow{10}{*}{$\begin{array}{l}\mathbf{F} \\
\mathbf{M} \\
\mathbf{F} \\
\mathbf{F} \\
\mathbf{M} \\
\mathbf{F} \\
\mathbf{F} \\
\mathbf{F} \\
\mathbf{F} \\
\mathbf{F} \\
\mathbf{M} \\
\mathbf{M} \\
\mathbf{M} \\
\mathbf{F} \\
\mathbf{M} \\
\mathbf{F} \\
\mathbf{F} \\
\mathbf{F} \\
\mathbf{M} \\
\mathbf{M} \\
\mathbf{M} \\
\mathbf{M} \\
\mathbf{F} \\
\mathbf{F} \\
\mathbf{M}\end{array}$} & \multirow{10}{*}{$\begin{array}{l}\text { Severe } \\
\text { Severe } \\
\text { Severe } \\
\text { Mild } \\
\text { Severe } \\
\text { Severe } \\
\text { Severe } \\
\text { Mild } \\
\text { Severe } \\
\text { Severe } \\
\text { Severe } \\
\text { Mild } \\
\text { Mild } \\
\text { Severe } \\
\text { Severe } \\
\text { Severe } \\
\text { Mild } \\
\text { Severe } \\
\text { Severe } \\
\text { Severe } \\
\text { Severe } \\
\text { Severe } \\
\text { Moderate } \\
\text { Moderate } \\
\text { Severe }\end{array}$} & \multirow{10}{*}{$\begin{array}{l}73-110 \\
48-55 \\
153 \\
17 \\
39-70 \\
65-70 \\
26-45 \\
14 \\
120 \\
160 \\
20 \\
17 \\
19.8 \\
28-105 \\
200 \\
50 \\
25 \\
32 \\
26 \\
27 \\
45 \\
50 \\
17-50 \\
28 \\
80\end{array}$} & \multirow{10}{*}{$\begin{array}{l}14-19 \\
12-13 \\
15-17 \\
12 \\
12 \\
12 \\
18 \\
18 \\
15.5 \\
12.8 \\
14.7 \\
11.5-14 \\
13-14 \\
21-22 \\
21-22 \\
11 \\
10 \\
13 \\
12.5 \\
11 \\
15 \\
11.2 \\
20\end{array}$} & Abnormal ${ }^{*}$ & \multirow[t]{2}{*}{ Not corrective* } \\
\hline & $\begin{array}{l}\text { Marciniakowna and associates (10) } \\
\text { Wurzel and associates (11) } \\
\text { Jenkins (12) }\end{array}$ & $\begin{array}{l}1953 \\
1954 \\
1954\end{array}$ & & & & & \multirow[t]{2}{*}{ Normal $\dagger$} & \\
\hline & Quick and associates (13) & 1955 & & & & & & \multirow{2}{*}{ Corrective (38) } \\
\hline & $\begin{array}{l}\text { Long and associates (14) } \\
\text { de Vries and associates (15) }\end{array}$ & 1955 & & & & & \multirow{2}{*}{$\begin{array}{l}\text { Abnormal } \\
\text { Abnormal } \\
\text { Abnormal } \\
\text { Normal }\end{array}$} & \\
\hline & $\begin{array}{l}\text { Hicks (16) } \\
\text { Hule and associates (17) }\end{array}$ & $\begin{array}{l}1955 \\
1955\end{array}$ & & & & & & \multirow[t]{5}{*}{ Corrective } \\
\hline & Koch and associates (18) & 1955 & & & & & \multirow{4}{*}{$\begin{array}{l}\text { Normal } \\
\text { Normal } \\
\text { Abnormal (?) } \\
\text { Abnormal } \\
\text { Abnormal }\end{array}$} & \\
\hline & Soulier and associates (19) & 1955 & & & & & & \\
\hline & Stefanovic and associates (20) & 1955 & & & & & & \\
\hline & Chevallier and associates (21) & 1955 & & & & & & \\
\hline & $\begin{array}{l}\text { Newcomb and associates (22) } \\
\text { Telfer and associates (23) } \\
\text { Jürgens (24) }\end{array}$ & $\begin{array}{l}1956 \\
1956 \\
1956\end{array}$ & & & & & $\begin{array}{l}\text { Abnormal } \\
\text { Abnormal } \\
\text { Normal }\end{array}$ & Corrective \\
\hline
\end{tabular}

* Work of present authors.

† Work of Ackroyd quoted and confirmed by Bergsagel and Hougie (41).

thrombin utilization in clotting blood was determined by the method described by Graham and associates (31). Partial thromboplastin time was determined by the method of Langdell, Wagner, and Brinkhous (33). In one experiment washed platelets were substituted for cephalin in this test. The platelets were prepared by differential centrifugation of citrated blood, suspension in a large volume of saline, recentrifugation, and resuspension in a volume of saline equal to one-fifth the original plasma volume. Prothrombin concentration was determined by the Iowa two-stage method as described by Wagner, Graham, Penick, and Brinkhous (34). Thrombin formation from partially purified human prothrombin was measured by the method of Biggs and Macfarlane (29). Prothrombin time was determined by the method of Quick (35). For some experiments this test was modified by increasing the total volume of reacting mixture to $0.4 \mathrm{ml}$. to allow the addition of test substances. In other experiments a sedimented platelet coagulant, Product II (43), or "Stypven" was substituted for brain extract. Thromboplastin generation test was performed by the technique of Biggs and Douglas (36). $p H$ of serum in stability studies was adjusted to desired values with a glass electrode $\mathrm{pH}$ meter (Beckman) at $25^{\circ} \mathrm{C}$ by adding suitable quantities of $0.1 \mathrm{~N} \mathrm{HCl}$ or $0.1 \mathrm{~N}$ $\mathrm{NaOH}$. Stuart factor concentration of serum and eluates was determined by correction of the patient's plasma clotting defect in a modified prothrombin time test. To $0.1 \mathrm{ml}$. of patient's plasma was added $0.1 \mathrm{ml}$. of brain extract, $0.1 \mathrm{ml}$. of normal control serum variously diluted with patient's serum, and $0.1 \mathrm{ml}$. of $0.025 \mathrm{M} \mathrm{CaCl}_{2}$. On these mixtures prothrombin times were determined in triplicate. From the average of the clotting times at each dilution a calibration curve was constructed by plotting prothrombin time against Stuart factor concentration, i.e., the per cent normal control serum in the mixture. The concentration of Stuart factor in samples of normal serum or eluate exposed to varying $\mathrm{pH}$ 's or temperatures was determined by interpolation from the calibration curve after substituting the test substance for control serum in the above system.

\section{CASE REPORT}

A white male farmer, R. S., now aged 36 , has had frequent epistaxes and hematomata; hemarthroses have 


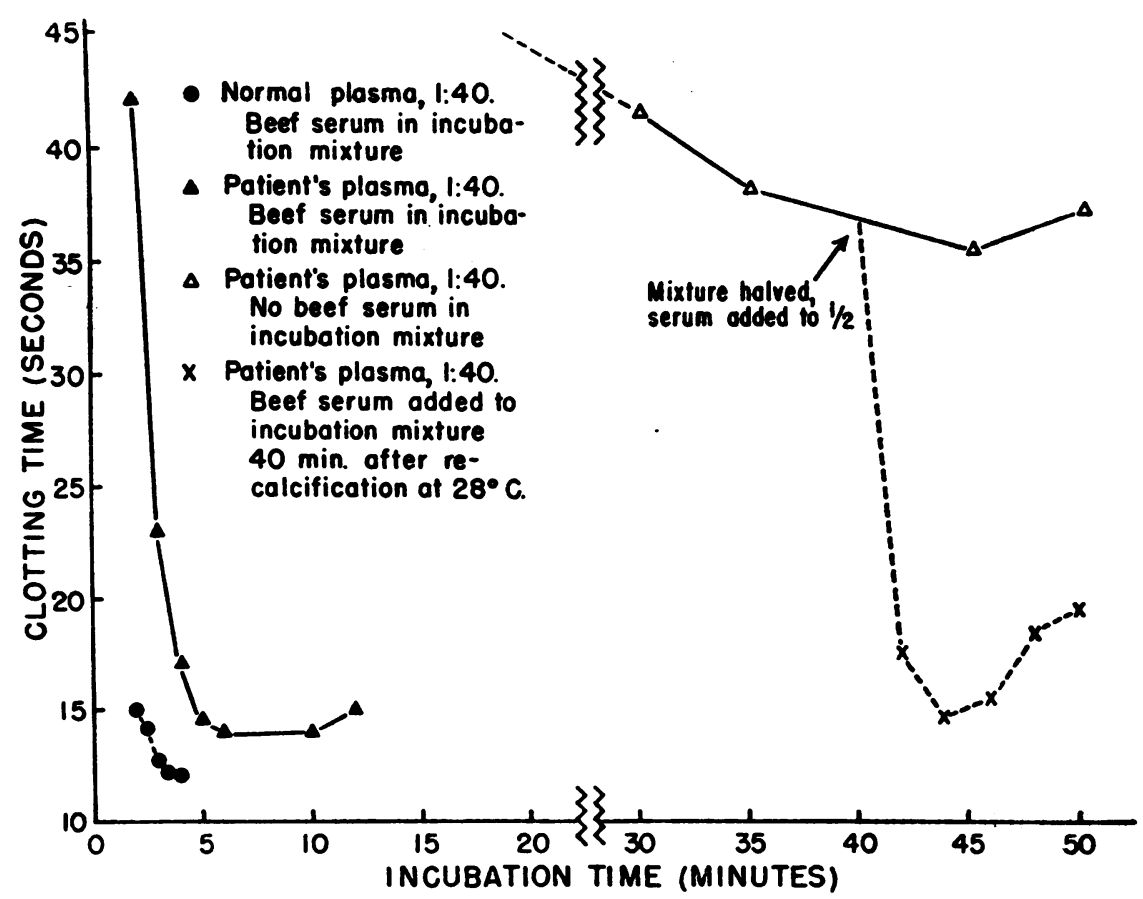

Fig. 1. Thrombin Eqolution from Prothrombin of Patient's Plasya nn a Two-Stage Prothrombin Assay When Saline was Substitutre for Stored Beep Serum in the Incubation Mixture Containing Lung Thromboplastin

All plasmas were diluted 1:40 before one part was added to three parts of the incubation mixture. At intervals $0.4 \mathrm{ml}$. of the mixture containing plasma and incubating at $28^{\circ} \mathrm{C}$ was added to $0.1 \mathrm{ml}$. of fibrinogen and the clotting times were recorded.

been infrequent and generally mild, but in December, 1955, there occurred a severe hemarthrosis of the right hip resulting in severe anemia. He received his first transfusion at this time, 1 unit of fresh blood, and apparently responded well. He now has five children with a sixth expected; the levels of the Stuart factor in the five tested varied between 21 per cent and 52 per cent of normal. Serum from the eldest son, aged 12, was used in an experiment described below. The boy's level of Stuart factor was 26 per cent of normal.

\section{RESULTS}

Study of the patient's blood, platelets, plasma and serum yielded the following results:

\section{Whole blood clotting time}

14 minutes (normal control 8 to 10 minutes).

\section{Prothrombin concentration}

Two hundred and twenty units, 86 per cent of control, when the two-stage incubation mixture contained stored beef serum. When saline was substituted for beef serum in the incubation mixture, only small amounts of thrombin were produced from the patient's prothrombin over a 40minute period. The addition of beef serum after 40 minutes resulted in the production of almost as much thrombin as when beef serum had been present initially (Figure 1).

\section{Prothrombin utilization}

Forty-six per cent prothrombin remained 60 minutes after venipuncture, indicating significant impairment of prothrombin utilization. This confirms the earlier work of Lewis, Fresh, and Ferguson (9) who stressed that prothrombin utilization was abnormal in this patient.

Effect of normal plasma and serum and their fractions on patient's modified prothrombin time

It can be seen from Table II that the prolonged prothrombin time of the patient's plasma was corrected by normal plasma and serum. Alumina- 
TABLE II

The effect of plasma, serum and serum fractions on the patient's modified prothrombin time

\begin{tabular}{|c|c|c|c|c|c|c|c|c|}
\hline & & \multicolumn{2}{|c|}{ Alumina adsorbed (cm.3) } & \multirow{2}{*}{\multicolumn{2}{|c|}{ Serum (cm. }} & \multirow{3}{*}{$\begin{array}{l}\text { Normal serum } \\
\text { eluate } \\
\text { (cm.s) }\end{array}$} & \multirow{3}{*}{$\begin{array}{l}\text { Saline } \\
\left(\mathrm{cm} . \mathrm{s}^{3}\right)\end{array}$} & \multirow{3}{*}{$\begin{array}{l}\text { Modified } \\
\text { prothrombir } \\
\text { time } \\
\text { (sec.) }\end{array}$} \\
\hline \multicolumn{2}{|c|}{ Plasma (cm.?) } & \multirow{2}{*}{$\begin{array}{c}\text { Normal } \\
\text { plasma } \\
\text { (undiluted) }\end{array}$} & \multirow{2}{*}{$\begin{array}{l}\text { Normal } \\
\text { gerum } \\
\text { dil. 1:5 }\end{array}$} & & & & & \\
\hline Normal & Patient & & & $\begin{array}{l}\text { Normal } \\
\text { dil. 1:5 }\end{array}$ & $\begin{array}{l}\text { Patient } \\
\text { dil. } 1: 5\end{array}$ & & & \\
\hline $\begin{array}{l}0.1 \\
0.05\end{array}$ & $\begin{array}{l}0.1 \\
0.05 \\
0.1 \\
0.1 \\
0.1 \\
0.1 \\
0.1\end{array}$ & 0.1 & 0.1 & 0.1 & 0.1 & 0.1 & $\begin{array}{l}0.1 \\
0.1 \\
0.1\end{array}$ & $\begin{array}{l}12.2 \\
85 \\
12.8 \\
13.2 \\
59.0 \\
62.8 \\
12.6 \\
68\end{array}$ \\
\hline
\end{tabular}

adsorbed normal plasma and serum were ineffective, while the phosphate buffer eluate from the alumina adsorbate of normal serum was active.

\section{Partial thromboplastin time}

Five hundred and ten seconds with 0.3 per cent cephalin (Normal control 66 secs.). Partial thromboplastin times were also performed on patient's and normal plasma using both patient's and normal washed platelets. The normal platelets clotted the patient's plasma in 137 seconds, the normal plasma in 75 seconds. Patient's platelets clotted the patient's plasma in 135 seconds and the normal plasma in 71 seconds. It would appear that Stuart factor, unlike Factor V (37), can be easily removed from normal platelet suspensions prepared from citrated blood. It also appears that the patient's defect does not lie in his platelets.

\section{Effect of "Stypven" on patient's clotting defect}

In four of the cases listed in Table I it has been found that Russell's viper venom gives a normal

TABLE III

Effect of "Stypuen" on clotting defect of patient's plasma

\begin{tabular}{|c|c|c|c|c|c|}
\hline \multicolumn{2}{|c|}{ Type of plasma } & \multirow{2}{*}{$\begin{array}{c}\text { Brain } \\
\text { extract } \\
\text { (am.") }\end{array}$} & \multirow{2}{*}{$\begin{array}{c}\text { "Stypven" } \\
10 \text { mg./100 ml. } \\
(\mathrm{cm.8})\end{array}$} & \multirow[b]{2}{*}{$\begin{array}{c}\text { Saline } \\
\left(\mathrm{cm} .{ }^{8}\right)\end{array}$} & \multirow{2}{*}{$\begin{array}{l}\text { Modified } \\
\text { prothrombin } \\
\text { time (sec.) }\end{array}$} \\
\hline $\begin{array}{c}\text { Patient } \\
\text { (cm.s) }\end{array}$ & $\underset{\left.(\mathrm{cm} .)^{\circ}\right)}{\text { Normal }}$ & & & & \\
\hline \multirow[b]{2}{*}{0.1} & 0.1 & 0.1 & \multirow{4}{*}{$\begin{array}{l}0.1 \\
0.1 \\
0.1 \\
0.1\end{array}$} & \multirow{4}{*}{$\begin{array}{l}0.1 \\
0.1 \\
0.1 \\
0.1\end{array}$} & \multirow{4}{*}{$\begin{array}{l}12.2 \\
85 \\
18.5 \\
27 \\
7.5 \\
22.5\end{array}$} \\
\hline & 01 & 0.1 & & & \\
\hline 0.1 & & & & & \\
\hline & 0.1 & $\begin{array}{l}0.1 \\
0.1\end{array}$ & & & \\
\hline
\end{tabular}

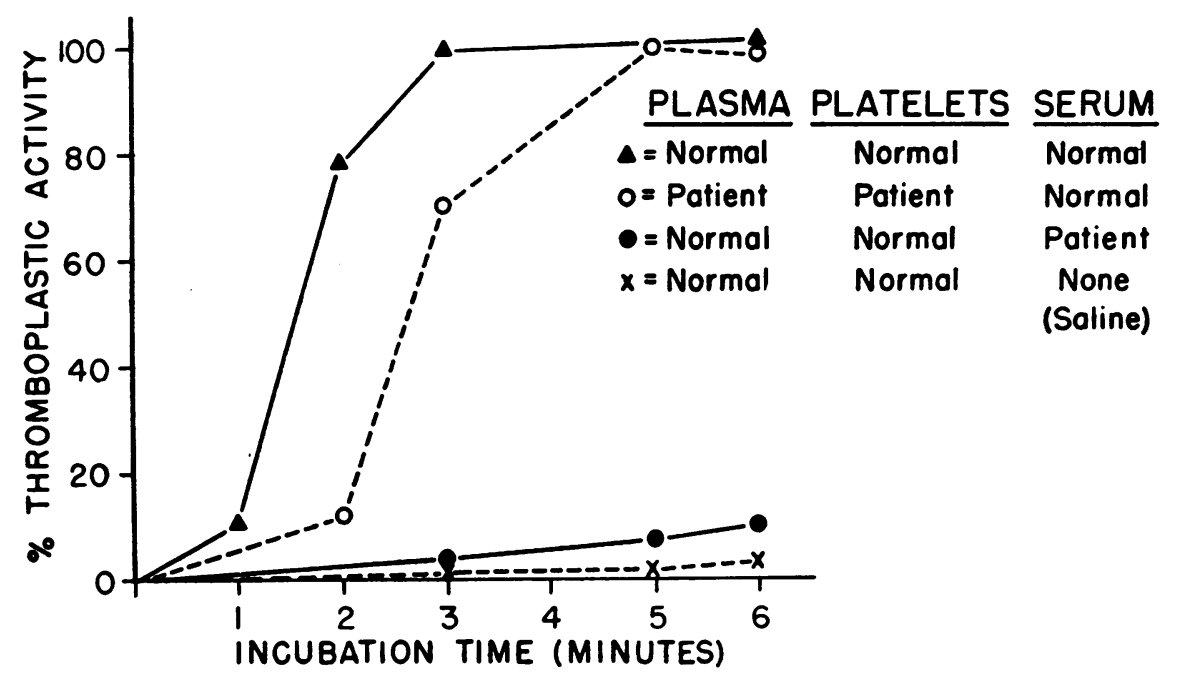

Fig. 2. Thromboplastin Generation Tests Performed on Mixtures of Vartous Reagents Prepared from Patient and Normal Control 


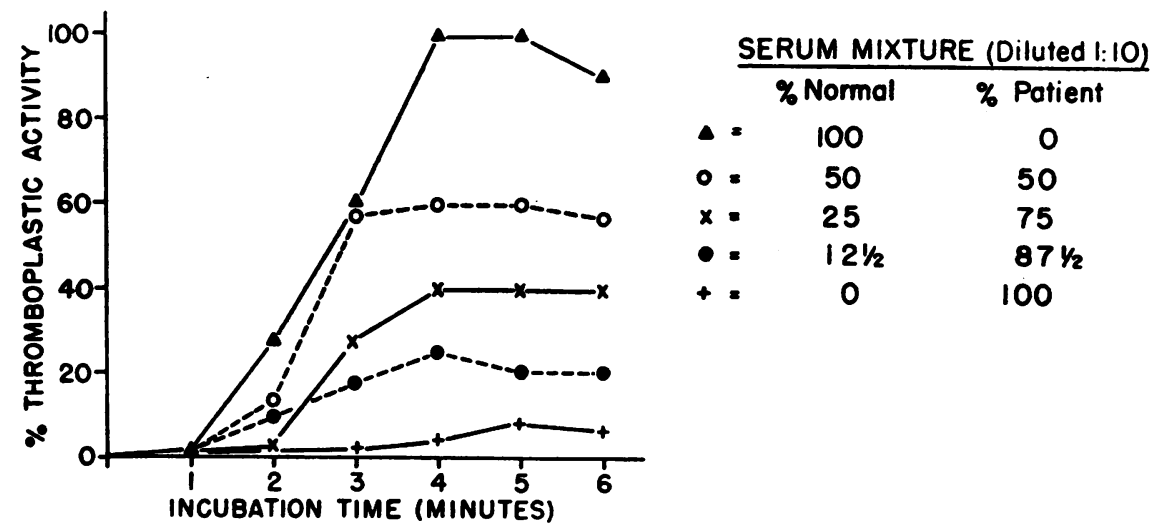

Fig. 3. Effect of Varying Concentrations of Stuart factor on the Production of Congulant Activity under the Conditions of the Thromboplastin Generation Test

$\mathrm{Al}(\mathrm{OH})_{3}$ adsorbed normal plasma and washed normal platelets were used in all mixtures.

"prothrombin time" while brain extract does not. "Stypven," like brain extract, did not give a normal "prothrombin time" with our patient's plasma (Table III). This was true also of a mixture of "Stypven" and brain extract. "Stypven" plus cephalin, and "Stypven" plus platelets in both $1: 10,000$ and $1: 20,000$ concentration also failed to give a normal "prothrombin time" with the plasma of Crockett's (25) patient.

\section{Thromboplastin generation test}

The patient's alumina-treated plasma and his platelets were active in the thromboplastin generation test, but his serum was inactive (Figure 2).
The thromboplastic activity produced when various mixtures of the patient's and normal serum were incubated with normal alumina-treated plasma, normal platelets and calcium is shown in Figure 3. It can be seen that the coagulant activity varied directly with the concentration of the Stuart factor. Prolonging the incubation period above 6 minutes did not result in a further increase in activity.

\section{Effect of plasma and serum from dicoumarolized patients on Stuart clotting defect}

Plasma from a patient obtained on the third day of dicoumarol therapy with a prolonged pro-

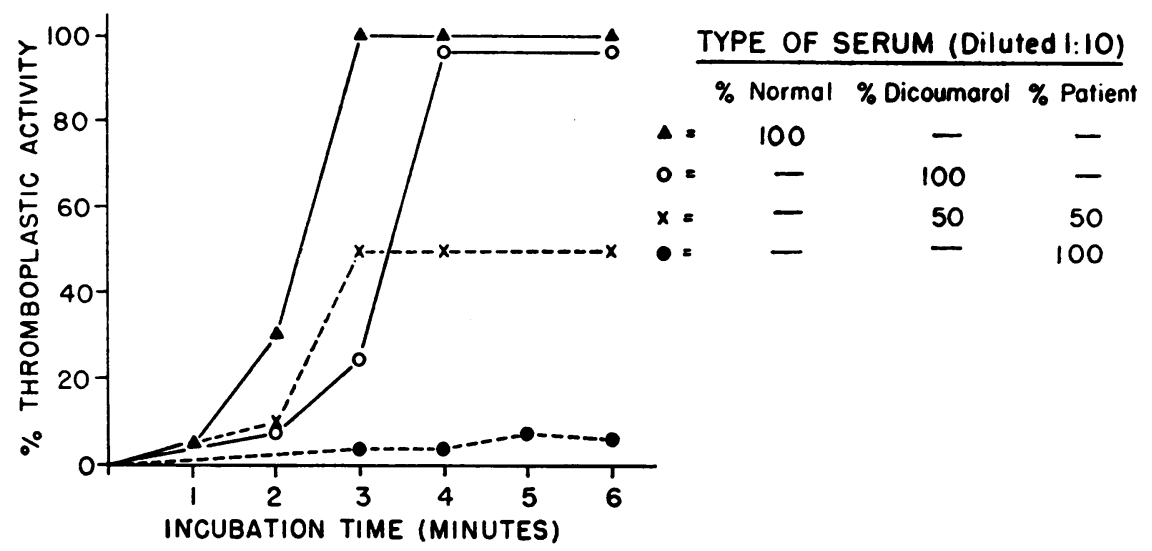

Fig. 4. Effect of Serum from a Dicoumarolized Patient on Patient's Serum in the Thromboplastin Generation TEST

$\mathrm{Al}(\mathrm{OH})$, adsorbed normal plasma and washed normal platelets were used in all systems. 
TABLE IV

Effect of normal and dicoumarol plasma on prothrombin time of patient's plasma

\begin{tabular}{lc}
\hline \multicolumn{1}{c}{ Type of plasma } & $\begin{array}{c}\text { Prothrombin } \\
\text { time (sec.) }\end{array}$ \\
\hline $0.1 \mathrm{ml}$. normal plasma & 13 \\
$0.1 \mathrm{ml}$. patient's plasma & 73 \\
$0.1 \mathrm{ml}$. dicoumarol plasma & 34 \\
$0.05 \mathrm{ml}$. normal plasma and & 19 \\
$0.05 \mathrm{ml}$ dicoumarol plasma & \\
$0.05 \mathrm{ml}$. patient's plasma and & 20 \\
$0.05 \mathrm{ml}$. dicoumarol plasma & \\
\hline
\end{tabular}

thrombin time was found to correct the prothrombin time of R. S.'s plasma almost as well as normal plasma (Table IV). It should be emphasized that serum prepared at the same time from this dicoumarolized patient was normal in the thromboplastin generation test (Figure 4), and the two-stage prothrombin concentration of the plasma was 70 per cent of normal, despite a plasma prothrombin time of 34 secs. It can be seen that equal mixtures of serum from this dicoumarolized patient and Stuart's serum (Figure 4) gave the same 50 per cent thromboplastic effect as was shown in Figure 3 with equal mixtures of normal serum and patient's serum. Most samples obtained from patients on dicoumarol at a later stage of treatment were found to be deficient in the Stuart factor. The prolongation of the plasma prothrombin time in this patient on dicoumarol for a short time must be attributed to a deficiency of some "brain extract co-factor" other than the Stuart factor, perhaps SPCA.

\section{Effect of PTC-deficient (Christmas disease) plasma and serum on Stuart clotting defect}

Plasma from a patient with PTC deficiency (Christmas disease) corrected the prolonged prothrombin time of the patient's plasma to the same extent as normal plasma. Also a mixture of equal parts PTC deficient serum $(1: 10)$ with patient's serum $(1: 10)$ produced the same amount of thromboplastic activity in the thromboplastin generation test as normal serum at a $1: 20$ dilution.

Role of the Stwart factor in thromboplastin formation

Biggs, Douglas, and Macfarlane (40) have shown that a plasma fraction rich in AHF undergoes a preliminary reaction with serum and calcium ions to form an intermediate product. This

TABLE $\nabla$

Effect of various types of serum on formation of sedimentable Product II*

\begin{tabular}{|c|c|c|c|c|c|c|}
\hline \multirow{3}{*}{$\begin{array}{l}\text { Type of serum in- } \\
\text { cubated with bovine } \\
\text { AHF, } 0.025 \mathrm{M} \mathrm{CaCl}_{2} \text {, } \\
\text { imidazole buffer }\end{array}$} & \multirow{7}{*}{\multicolumn{3}{|c|}{ 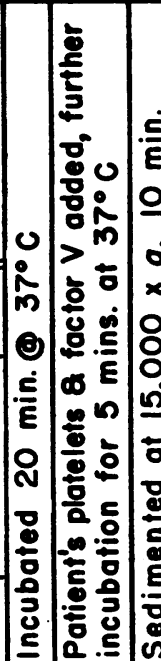 }} & \multirow{5}{*}{ 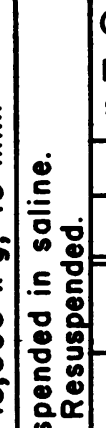 } & \multirow{2}{*}{\multicolumn{2}{|c|}{$\begin{array}{l}\text { C.T. (secs) of } 0.1 \mathrm{ml} \text { platelet-poor } \\
\text { plasma, } 0.1 \mathrm{ml} \text { of once washed } \\
\text { sediment, } 0.025 \mathrm{M} \mathrm{CaCl}_{2} \\
\text { Type of Plosmo }\end{array}$}} \\
\hline & & & & & & \\
\hline & & & & & Normal & Patient's \\
\hline Normal Serum & & & & & 15 & 13 \\
\hline Patient's Serum & & & & & 60 & 73 \\
\hline $\begin{array}{l}\text { PTC-deficient } \\
\text { Serum }\end{array}$ & & & & 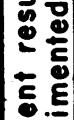 & 40 & 43 \\
\hline $\begin{array}{c}\text { Serum of patient's } \\
\text { son }\end{array}$ & & & & 辰 & 23 & 23 \\
\hline
\end{tabular}

* Mixtures consisted of $0.5 \mathrm{ml}$. bovine AHF ( $100 \mathrm{mg}$. per $100 \mathrm{ml}$ ) $0.5 \mathrm{ml}$. imidazole buffer, $0.5 \mathrm{ml}$. of $0.025 \mathrm{M} \mathrm{CaCl}_{2}$ and $0.5 \mathrm{ml}$ of each type of serum. Normal serum was diluted 1:20, the other sera $1: 10$. After preliminary incubation, $0.5 \mathrm{ml}$. of a suspension of patient's platelets and $0.2 \mathrm{ml}$. of Factor $\mathrm{V}$ were added to each mixture. 
product has been referred to as Product I for convenience alone, since it has not been claimed or shown that this is the first intermediate formed. Product $I$ is believed to react with platelets, resulting in the formation of a sedimentable product (Product II) with powerful thromboplastic properties. These Product II sediments can be washed at least twice in saline without losing their potency (41). Serum from a patient with congenital PTC deficiency was found to be inactive in this system, and PTC was considered, therefore, to be necessary for formation of Product $I$. This view was supported by the finding that a "purified" PTC preparation, prepared by the method of White, Aggeler, and Glendening (42) and containing less than 5 per cent Factor VII when assayed by the technique of Koller, Loeliger, and Duckert (3), could be substituted for normal serum.

An experiment was devised to determine the role of Stuart factor in the formation of Product II. A mixture consisting of AHF, imidazole buffer, and $\mathrm{CaCl}_{2}$ was preincubated at $37^{\circ} \mathrm{C}$ separately with normal serum, the patient's serum, PTC deficient (Christmas disease) serum, or serum from the patient's son with only 26 per cent Stuart factor. "Product II" was prepared from each mixture as shown in detail in Table V, and the relative coagulant activities of the various washed and resuspended deposits were tested on platelet-poor plasma.

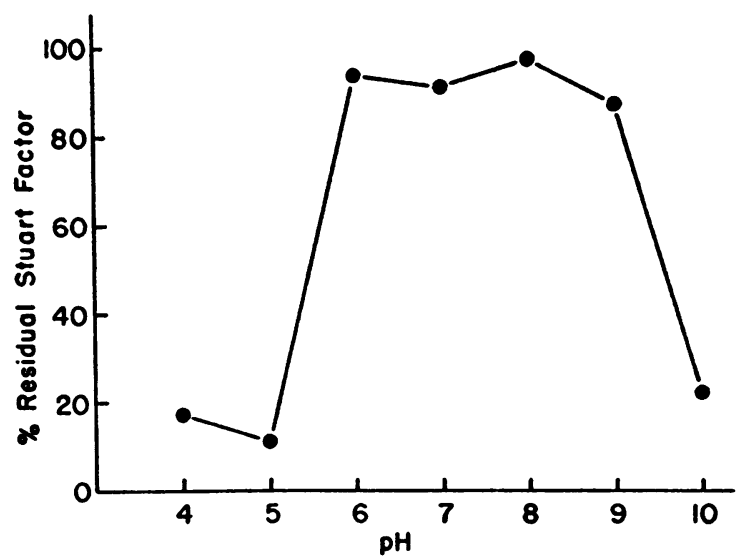

Fig. 5. EfFect of $\mathrm{H}^{+}$Concentration on Stuart Factor Concentration of Serum Exposed to Various PH'S 30 MIN. AT $37^{\circ} \mathrm{C}$

The volumes of the control and various treated sera were adjusted to a common volume with $0.1 \mathrm{~N} \mathrm{NaCl}$ after the pH's had been returned to 7.3.
TABLE VI

The stability of Stuart factor with time and temperature

\begin{tabular}{lccc}
\hline \hline Material treated & $\begin{array}{c}\text { Temperature } \\
(\odot \mathrm{C})\end{array}$ & $\begin{array}{c}\text { Length of } \\
\text { expoeure }\end{array}$ & $\begin{array}{c}\text { \% realdual } \\
\text { stuart factor }\end{array}$ \\
\hline Oxalated serum & 28 & $120 \mathrm{hrs.}$ & 78 \\
Oxalated serum & 28 & $168 \mathrm{hrs}$. & 70 \\
Oxalated serum & 37 & $240 \mathrm{hrs.}$ & 25 \\
Oxalated serum & 45 & 6 mins. & 99 \\
Oxalated serum & 56 & $2 \frac{1}{\text { mins. }}$ & 22 \\
Oxalated serum & 56 & 30 mins. & 2 \\
Oxalated serum & 65 & 30 mins. & 0 \\
Eluate in saline* & 50 & 30 mins. & 100 \\
Eluate in saline* & 56 & 21 mins. & 82 \\
Eluate in saline* & 56 & 30 mins. & 45 \\
Eluate in saline* & 65 & 30 mins. & 29 \\
\hline
\end{tabular}

* Eluate prepared by adsorbing oxalated serum with $\mathrm{BaSO}_{4}, 40 \mathrm{mg}$. per ml., eluting with 3.2 per cent sodium citrate, dialyzing against cold oxalated saline for 2 to 3 hours with three changes.

It can be seen that the Stuart factor, as well as PTC, was necessary for the formation of the active sediment. The sediment prepared from the serum of the patient's son showed that partial reduction in Stuart factor reduced somewhat the activity of Product II. The sedimentable thromboplastin prepared with normal serum, it should be noted, gave a normal clotting time with the patient's plasma despite the rinse in saline. Thus the sedimentable product had an effect not possessed by brain extract (Table II), lung thromboplastin (Figure 1) or washed normal platelets prepared from citrated plasma. It appears to be a fair assumption from this experiment that our patient's clotting defect lies primarily in the failure to form "blood thromboplastin" as in Christmas disease.

\section{Properties of Stuart factor}

The stability of the Stuart factor in serum exposed to different $\mathrm{H}^{+}$concentrations for $30 \mathrm{~min}$ utes at $37^{\circ} \mathrm{C}$ is shown in Figure 5. Stuart factor in a serum medium was quite stable in the $\mathrm{pH}$ range from 6 to 9 although largely inactivated outside this range.

The stability of the Stuart factor with time and temperature is shown in Table VI. The factor in a serum medium was moderately stable at temperatures up to $56^{\circ} \mathrm{C}$. However, most of the activity disappeared when serum was heated at $56^{\circ} \mathrm{C}$ or higher. Heating the citrate eluate from barium sulphate adsorption of a sample of the same serum at $56^{\circ} \mathrm{C}$ caused much less loss of activity. 


\section{Effect of patient's plasma and serum on clotting defect of a case of congenital deficiency of SPCA}

Lyophilized samples of the patient's plasma and serum were sent to Dr. Benjamin Alexander who found that the plasma of his patient (1) (congenital deficiency of SPCA by prior definition) and the plasma of our patient were mutually corrective in the prothrombin time test. Dr. Alexander has informed us that the thromboplastin generation test is normal in his patient (43). He has also found that both patients appear to lack "proconvertin" as measured by Owren's technique' (6), and that a mixture of equal parts of the plasmas of the two patients appears to have 50 per cent "proconvertin" activity in the Owren assay. These data suggest strongly that the defects in the two patients should be considered distinct.

\section{Effect of patient's plasma and serum on clotting defect of case of Crockett and associates}

Crockett and associates (25) studied a patient (H. H.) with a congenital clotting defect. This patient had a prolonged prothrombin time which was corrected by normal serum. It can be seen (Table VII) that a normal prothrombin time was not obtained when equal parts of the plasma of the above patient and the plasma of R. S. were mixed, although mixture with normal plasma was successful with both patients. It was shown also that the two sera were not mutually corrective in the thromboplastin generation test, an equal mixture of each being inactive. The defects in the two cases, therefore, can be considered the same.

TABLE VII

The effect on patient's plasma, of normal plasma and the plasma of a previously described patient with a clotting defect

\begin{tabular}{llcc}
\hline \hline & Plasma & & \\
\cline { 2 - 4 } R. S. & H. H. & Normal & $\begin{array}{c}\text { Prothrombin } \\
\text { time (sec.) }\end{array}$ \\
\hline & & 0.1 & 12.2 \\
0.1 & 0.1 & & 38 \\
0.05 & 0.05 & & 60 \\
0.05 & 0.05 & 0.05 & 44 \\
& & 0.05 & 13.4 \\
\hline
\end{tabular}

\section{DISCUSSION}

The direct mixing of the plasmas of our patient and Alexander's with mutual correction of the prolonged prothrombin times, plus the completely different action of the two in the thromboplastin generation test indicate that the two defects are not identical. Thus, a patient diagnosed as having SPCA deficiency and one diagnosed as having proconvertin deficiency have different defects. This throws open the whole question of the action of these factors and requires that the literature be re-evaluated in the light of this finding. The puzzling inconsistencies in Table I with regard to thromboplastin generation and "Stypven" action are probably explained by heterogeneity of the cases.

It would be interesting to know the effect of "Stypven" on the plasma of Alexander's patient. The fact that "Stypven" failed to correct the defect of both our patient and Crockett's, yet corrected the defects of Hicks' (16) and Jenkins' (38) patients with Factor VII deficiency, Hjort, Rapaport, and Owren's with hypoproconvertinemia (39) and Telfer, Denson, and Wright's with "Prower factor" deficiency (23) suggests that "Stypven" might prove useful in categorizing bleeders with a prolonged prothrombin time due to absence of one of the "stable" factors.

It is of great interest that the Stuart factor is required for "thromboplastin" formation in the thromboplastin generation test while SPCA is not (43). This parallels the finding of delayed prothrombin utilization in our patient $(9$, present paper) and normal prothrombin utilization in Alexander's (1). The abnormal prothrombin utilization in our patient is confirmed and explained by our in vitro experiments. In the experiment shown in Figure 1, thrombin evolution from prothrombin of the patient's plasma in a 2stage prothrombin assay was markedly abnormal unless a serum factor was added. We have found also that the yield of thrombin from partially purified human prothrombin (29) is proportional to the concentration of "Product II," in additional experiments not included in the present communication. Thus there appears to be a direct relationship between Stuart factor concentration and activity of Product II on the one hand, and concentration of Product II and the yield of 
thrombin from prothrombin on the other. The prothrombin utilization defect in our patient appears secondary to defective formation of blood thromboplastic activity.

The experiments with the washed sediments (Table V) show clearly that the Stuart factor is as necessary as AHF and PTC for the formation of the early intermediate, Product I, which appears to unite in some manner with platelets to form a sedimentable thromboplastin, Product II. The sedimentable Product II, after a wash in saline, gives the same normal "prothrombin time" with the patient's plasma as with normal plasma, suggesting from another direction that the patient's defect in conversion of prothrombin to thrombin is the reflection of a defect in the formation of a "complete" blood thromboplastin. The facts that washed normal platelets alone do not correct the patient's defect while the washed Product II prepared with normal serum does correct it, seem to imply that the Stuart factor in the Product II sediments is more closely bound to platelets than mere occluded plasma.

Retrospectively, it would appear that the chief reason for the assumed identity of Factor VII, SPCA, and proconvertin has been the wide use of assays of the Koller (3) and Owren (4) types. The substrate for both methods consists of plasma filtered through asbestos. This substrate is known to contain most of its original prothrombin but has been thought to be deficient in only a single accessory factor. Alexander (43) has found that the plasmas of both his patient and ours appear to lack proconvertin by the Owren method (4), while an equal mixture of the two has approximately half the activity of normal plasma. This suggests that the asbestos filtration step has removed both SPCA and Stuart factor.

It is interesting that a "brain extract co-factor," which is not the Stuart factor, is depressed early in dicoumarol therapy. There is a short period, in other words, early during dicoumarolization when the prothrombin time is lengthened yet Factor $\mathrm{V}$ and prothrombin concentration are high, Stuart factor and PTC levels are not significantly reduced, and the thromboplastin generation test is normal. Later during therapy the Stuart factor becomes reduced along with PTC (44-46) and prothrombin (47).

The dicoumarol experiments raise the question whether the Stuart factor is identical with the postulated new factor, Factor $X$ (48) since the Factor $\mathrm{X}$ effect was first noted in dicoumarol plasma. Factor $\mathrm{X}$ appears to be less stable than the Stuart factor, since Factor $X$ is said to disappear in a few hours at room temperature (48), and the Stuart factor is stable much longer under similar conditions. Moreover, Factor $\mathrm{X}$ in concentrations varying between 1 per cent and 100 per cent is thought to affect the velocity of blood thromboplastin formulation but not the final yield (48), although in concentrations lower than 1 per cent, thromboplastin generation may be almost impossible (48). Our experiments show that the amount of coagulant activity produced in the thromboplastin generation test is related directly to Stuart factor concentration. It would appear that the Stuart factor is not the same as Factor X.

The $\mathrm{pH}$ and storage stabilities of Stuart factor are pronounced for a clotting factor and almost identical with those shown for SPCA by de Vries, Alexander and Goldstein (2). Since it has been demonstrated that Alexander's patient and ours have different defects, this poses a serious problem in interpretation. There are at least two possible explanations for the similarity of the properties of SPCA and Stuart factor. Either the two factors have very similar physical and chemical though different physiological properties, or de Vries and associates (2) were measuring Stuart factor in their SPCA assay rather than the factor which their patient (later described) was found to lack. It would be very interesting to compare the results obtained if their experiments were repeated, using the genetically deficient SPCA plasma as the test substrate alongside the original assay.

Heretofore, it has been agreed that the factors which are clearly essential for a normal thromboplastin generation test (AHF and PTC) have no effect on prothrombin time. Also, the "stable" factor essential for a normal prothrombin time (SPCA, Factor VII) has been recognized as having an equivocal relation to thromboplastin generation. The Stuart factor appears to be necessary for both a normal prothrombin time and for a normal thromboplastin generation test. This is disturbing because the characteristics of Stuart factor cut across our usual thought categories. It 
raises the question whether the Stuart defect is not, in reality, a double deficiency. This question cannot be answered categorically at present, because of the omnipresent possibility of undescribed factors. However, it seems unlikely for two reasons. It has been shown previously that Stuart's plasma (then thought to be SPCA-deficient) corrects the prolonged partial thromboplastin time of plasmas from classic hemophilia, PTC-deficiency, Ac-globulin deficiency, and PTA deficiency (49). Alexander has shown that it also corrects SPCA deficient plasma (43), and it does not have the characteristics of Hageman factor (50) or Factor X (48). The hypothesis of double deficiency would imply under these circumstances that the plasma is deficient in two new factors. The principle of economy of hypotheses suggests that it might be wise to invoke only one new factor at this time. Secondly, if the conventional genetic assumption that each of these deficiencies results from a mutant gene at a specific and unique locus is made, the probability of a double deficiency can be shown to be exceedingly small.

It is not possible at present to decide with certainty which of the reported cases of SPCA, Factor VII and proconvertin deficiency probably match Alexander's patient and which ours. Retesting all of the patients with both the thromboplastin generation test and "Stypven" would be helpful. However, mutual exchange and crossmatching in several clotting systems appears to be the ultimate test. Of the patients in the literature (other than Crockett's), our patient's defect more nearly resembles that of de Vries' patients (15), Stefanovic's (20), Newcomb's (22) and Telfer's (23), the ones having abnormal thromboplastin generation tests. However, and this may be crucial, the Prower defect of Telfer's patient is corrected by "Stypven" in marked contrast to both our patient and Crockett's. This may well mean that the Stuart and Prower defects are different. The absence of tests with "Stypven" does not allow one to speculate further about the others. It is possible also that Quick, Pisciotta, and Hussey (13) have cases of both Stuart factor and SPCA deficiency amongst their patients with prolonged prothrombin times but showing mutual correction. At the moment, this possibility is obscured by the lack of two-stage prothrombin data as well as thromboplastin generation and "Styp- ven" tests. We would like to suggest, and are prepared to cooperate ourselves, that the workers who have reported cases of "stable factor" deficiency exchange lyophilized samples of plasma and serum in an attempt to categorize these patients exactly.

\section{CONCLUSIONS}

1. A patient was re-studied who had been diagnosed previously as hypoproconvertinemia. $\mathrm{He}$ had an abnormal thromboplastin generation test, and his defect was not corrected by "Stypven."

2. The deficient factor was shown not to be SPCA by cross-matching and is being called the Stuart factor after the patient's surname.

3. Stuart factor has been found to be essential for the formation of "blood thromboplastin."

4. Stuart factor has unusual actions, being necessary early in "blood thromboplastin" formation and required for optimal activity of brain, lung, and platelet thromboplastins, cephalin and "Stypven."

5. The concentration of Stuart factor has been found to be high early in dicoumarol therapy, despite a prolonged prothrombin time, but to be diminished later.

6. Stuart factor is relatively heat and $\mathrm{pH}$ stable.

7. Stuart factor can be separated from platelets by a single saline wash, but is not removed from the sedimentable coagulant, "Product II," by a similar procedure.

8. Assay procedures for "proconvertin" and "Factor VII" using asbestos-adsorbed plasma as substrate are probably sensitive to changes in the levels of both SPCA and Stuart factor.

9. The hemorrhagic state(s) previously classified as congenital "hypoproconvertinemia," or "SPCA deficiency" or "Factor VII deficiency" are probably not identical diseases. There are at least two separable conditions included in this group.

\section{REFERENCES}

1. Alexander, B., Goldstein, R., Landwehr, G., and Cook, C. D., Congenital SPCA deficiency: a hitherto unrecognized coagulation defect with hemorrhage rectified by serum and serum fractions. J. Clin. Invest., 1951, 30, 596.

2. de Vries, A., Alexander, B., and Goldstein, R., A factor in serum which accelerates the conversion of prothrombin to thrombin: I. Its determination 
and some physiologic and biochemical properties. Blood, 1949, 4, 247.

3. Koller, F., Loeliger, A., and Duckert, F., Experiments on a new clotting factor (factor VII). Acta haemat., 1951, 6, 1.

4. Owren, P. A., Proconvertin, the new clotting factor. Scandinav. J. Clin. \& Lab. Invest., 1951, 3, 168.

5. Beaumont, J. L., and Bernard, J., Syndrome hémorragique congénital dû au défaut du facteur de coagulation récemment isolé sous le nom de facteur VII, convertine, S.P.C.A. Acta med. Scandinav., 1953, 145, 200.

6. Owren, P. A., Prothrombin and accessory factors : clinical significance. Am. J. Med., 1953, 14, 201.

7. Hagen, P. S., and Watson, C. J., Idiopathic (familial) hypoprothrombinemia. J. Lab. \& Clin. Med., 1948, 33, 542.

8. Frick, P. G., and Hagen, P. S., Congenital familial deficiency of the stable prothrombin conversion factor; restudy of case originally reported as "idiopathic hypoprothrombinemia." J. Lab. \& Clin. Med., 1953, 42, 212.

9. Lewis, J. H., Fresh, J. W., and Ferguson, J. H., Congenital hypoproconvertinemia. Proc. Soc. Exper. Biol. \& Med., 1953, 84, 651.

10. Marciniakowna, E., Krakowska, J., Bober, S., and Safarzynska, I., Przypadek skazy krwotocznej wskutek niedoboru akceleratora konwersji protombiny. Polski tygodnik lek., 1953, 8, 1601.

11. Wurzel, H. A., Roth, K., and Zubrow, S., Mild familial hypoproconvertinemia. J. Lab. \& Clin. Med., 1954, 44, 403.

12. Jenkins, J. S., Haemorrhagic diathesis due to deficiency of factor VII. J. Clin. Path., 1954, 7, 29.

13. Quick, A. J., Pisciotta, A. V., and Hussey, C. V., Congenital hypoprothrombinemic states. Arch. Int. Med., 1955, 95, 2.

14. Long, L. A., Letendre, P., and Colpron, G., Hypoproconvertinémie congénitale. Acta haemat., 1955, 13, 242.

15. de Vries, S. I., Kettenborg, H. K., and van der Pol, E. T., Haemorrhagic diathesis due to a deficiency of factor VII (hypoproconvertinaemia). Acta haemat., 1955, 14, 43.

16. Hicks, N. D., A coagulation disorder due to a factor VII-like defect. M. J. Australia, 1955, 2, 331.

17. Hule, V., Sabacký, J., and Saxl, O., Ein Fall von angeborenem Mangel von Faktor VII (SPCAMangel, Hypoproconvertinaemia Congenita). Helvet. paediat. acta, 1955, 10, 419.

18. Koch, Fr., Schultze, H. E., Schwick, G., and Beller, F. K., Beobachtungen bei angeborenem Faktor VII-Mangel (Hypokonvertinämie). Ztschr. $f$. Kinderh., 1955, 76, 208.

19. Soulier, J. P., Alagille, D., Martin, C., and Buhot, S., Un cas d'hypoconvertinémie congénitale. Sang, $1955,26,660$.
20. Stefanovic, S., Milosavljevic, A., and Stefanovic, R., Deux cas d'hypoconvertinémie congénitale. Sang, 1955, 26, 315.

21. Chevallier, P., Bernard, J., Bilski-Pasquier, G., Samama, M., and Cerf, $P$. , L'hypoconvertinémie constitutionelle. Bull. et mém. Soc. méd. d. hôp. de Paris, 1955, 71, 679.

22. Newcomb, T., Matter, M., Conroy, L., DeMarsh, Q. B., and Finch, C. A., Congenital hemorrhagic diathesis of the prothrombin complex. Am. J. Med., 1956, 20, 798.

23. Telfer, T. P., Denson, K. W., and Wright, D. R., A 'new' coagulation defect. Brit. J. Haemat., 1956, 2, 308.

24. Jürgens, J., Kongenitaler Factor VII (SPCA)Mangel als Ursache einer hämophilie-artigen hämorrhagischen Diathese. Acta haemat., 1956, $16,181$.

25. Crockett, C. L., Shotton, D., Craddock, C. G., and Leavell, B. S., Hypoprothrombinemia: studies of a case of the idiopathic type and the effect of serum administration. Blood, 1949, 4, 1298.

26. Graham, J. B., Barrow, E. M., and Hougie, C., Stuart clotting defect. II. Genetic aspects of a 'new' hemorrhagic state. J. Clin. Invest., 1957, 36, 497.

27. Mertz, E. T., and Owen, C. A., Imidazole buffer: its use in blood clotting studies. Proc. Soc. Exper. Biol. \& Med., 1940, 43, 204.

28. Owren, P. A., The coagulation of blood. Investigations on a new clotting factor. Acta med. Scandinav., 1947, 128, Suppl. 194, p. 82 ff.

29. Biggs, R. P., and Macfarlane, R. G., Human Blood Coagulation and Its Disorders. Oxford, Blackwell Scientific Publications Ltd., 1953, Appendix II, III.

30. Bidwell, E., The purification of bovine antihaemophilic globulin. Brit. J. Haemat., 1955, 1, 35.

31. Graham, J. B., McLendon, W. W., and Brinkhous, K. M., Mild hemophilia: an allelic form of the disease. Am. J. M. Sc., 1953, 225, 46.

32. Lee, R. I., and White, P. D., A clinical study of the coagulation time of blood. Am. J. M. Sc., 1913, 145, 495.

33. Langdell, R. D., Wagner, R. H., and Brinkhous, $\mathbf{K}$. M., Effect of antihemophilic factor on one-stage clotting tests. A presumptive test for hemophilia and a simple one-stage antihemophilic factor assay procedure. J. Lab. \& Clin. Med., 1953, 41, 637.

34. Wagner, R. H., Graham, J. B., Penick, G. D., and Brinkhous, K. M., Estimation of prothrombin by the two-stage method in The Coagulation of Blood: Methods of Study, L. M. Tocantins, Ed., New York, Grune and Stratton, 1955, pp. 105-111.

35. Quick, A. J., The clinical application of the hippuric acid and the prothrombin tests. Am. J. Clin. Path., 1940, 10, 222.

36. Biggs, R., and Douglas, A. S., The thromboplastin generation test. J. Clin. Path., 1953, 6, 23. 
37. Hjort, P., Rapaport, S. I., and Owren, P. A., Evidence that platelet accelerator (platelet factor I) is adsorbed plasma proaccelerin. Blood, 1955, 10, 1139.

38. Jenkins, J. S., The thromboplastic activity of Russell's viper venom and its relationship to factor VII. J. Clin. Path., 1954, 7, 287.

39. Hjort, P., Rapaport, S. I., and Owren, P. A., A simple, specific one-stage prothrombin assay using Russell's viper venom in cephalin suspension. J. Lab. \& Clin. Med., 1955, 46, 89.

40. Biggs, R., Douglas, A. S., and Macfarlane, R. G., The initial stages of blood coagulation. J. Physiol., 1953, 122, 538.

41. Bergsagel, D. E., and Hougie, C., Intermediate stages in the formation of blood thromboplastin. Brit. J. Haemat., 1956, 2, 113.

42. White, S. G., Aggeler, P. M., and Glendening, M. B., Plasma thromboplastin component (PTC). A hitherto unrecognized blood coagulation factor. Case report of PTC deficiency. Blood, 1953, 8, 101.

43. Alexander, B., 1956, Personal communication.

44. Douglas, A. S., The coagulation defect caused by tromexan therapy. Clin. Sc., 1955, 14, 601.
45. Sise, H. S., Kimball, D. M., and Adamis, D., Plasma thromboplastin component (PTC) deficiency produced by prolonged administration of prothrombopenic anticoagulants. Proc. Soc. Exper. Biol. \& Med., 1955, 89, 81.

46. Douglas, A. S., Mode of action of coumarin drugs. Brit. M. Bull., 1955, 11, 39.

47. Overman, R. S., Stahmann, M. A., Sullivan, W. R., Huebner, C. F., Campbell, H. A., and Link, K. P., Studies on the hemorrhagic sweet clover disease. VII : The effect of 3,3'-methylenebis (4 hydroxycoumarin) on the prothrombin time of the plasma of various animals. J. Biol. Chem., 1942, 142, 941.

48. Duckert, F., Flückiger, P., Matter, M., and Koller, F., Clotting factor X. Physiologic and physicochemical properties. Proc. Soc. Exper. Biol. \& Med., 1955, 90, 17.

49. Brinkhous, K. M., Langdell, R. D., Penick, G. D., Graham, J. B., and Wagner, R. H., Newer approaches to the study of hemophilia and hemophilioid states. J. A. M. A., 1954, 154, 481.

50. Ratnoff, O. D., and Colopy, J. E., A familial hemorrhagic trait associated with a deficiency of a clotpromoting fraction of plasma. J. Clin. Invest., 1955, 34, 602 . 